\title{
Relationships Between Corporate Governance and Perceived Financial Performance of Firms: A Study
}

\author{
Derviş Boztosun, Semra Aksoylu \\ Erciyes University, Kayseri, Turkey
}

\begin{abstract}
Corporations should have strong capital to sustain their operations. Investors should feel safe and be able to have access to accurate information about firms to invest their capital in those firms. These two factors are vital issues for the sustainability of corporations in the 21 st century business. With the proper establishment of corporate governance practices, investors will be protected and feel safe and then a trust will develop, capital inflow will be facilitated and ultimately corporations with stronger financial foundations will emerge. A questionnaire was applied in this study to investigate the relationships between the corporate governance and perceived financial performance of the top 100 manufacturing firms operating in the Kayseri Organized Industrial Region. The results revealed that the number of employees had significant effects on the corporate governance and perceived financial performance scores of the firms and institutionalization level also affected perceived financial performance. The other independent variables (sectoral distribution, firm age, and export/revenue ratio) did not have any significant effects on corporate governance and perceived financial performance scores of the firms.
\end{abstract}

Keywords: corporate governance, perceived performance, financial performance

\section{Introduction}

Corporate governance has been envisaged as a solution in many countries to corporate scandals and corruptions, especially since the 1980s and has become the most discussed and investigated issue since the beginning of the 1990s. The corporate governance concept has been implemented in Turkey on a voluntary basis in recent years, but the concept gained a legal ground in 2012. Today, the concept of corporate governance has become a significant item in the agendas of various organizations and individuals ranging from regulatory bodies to corporations, stock markets to investors, corporate managers to employees, non-governmental organizations to audit companies, and from researchers to students.

Corporate governance is a combination of the compulsory and voluntary practices of a corporation to attract financial and human resources, to improve efficiency and allow shareholders to make economic gains in the long run and ultimately to improve their own welfares without creating any damage to shareholders and public interests. The problem of representation arising from the separation of shareholders from directors, in other words, the separation of capital from governance and control, has had a significant role in the emergence of the concept of corporate governance. It is at this point that shareholders have different expectations and executives have conflicts of interest. Corporate governance has, therefore, a major function at this point.

Derviş Boztosun, associate professor, Colleges of Applied Sciences, Erciyes University. Email: dboztosun@erciyes.edu.tr. Semra Aksoylu, associate professor, Colleges of Applied Sciences, Erciyes University. 
Corporate governance targets the minimization of such conflicts of interests which arise from the problem of representation and tries to regulate any possible negative actions for shareholders through using the information the directors have.

Corporations should have sufficient capital to survive and continue their operations. Investors want to feel secure and to be able to have access to accurate and reliable information about corporations when placing their capital in the hands of those corporations. With the establishment of corporate governance practices in companies, investors will be protected and the resultant confidence will facilitate capital inflow to corporations and then corporations with more powerful financial bases will emerge. Individual savings will also be contributed to the economy, transformed into production and ultimately will improve social welfare.

\section{Theoretical Framework and Literature}

\section{Corporate Governance}

Economic crises and large corporate scandals have given rise to the concept of corporate governance. In particular, with the separation of governance from ownership in corporates, a conflict of "principle administrator" has emerged. The solution to such a conflict is the primary target of corporate governance (Ar1, 2008).

There is no single worldwide-accepted definition of corporate governance. It can be defined in various ways based on where, how, and who is using it or which organization or institution issues the relevant principles.

Corporate governance is defined as to establish a balance between economic and social targets and between individual and social goals; to promote accountability in efficient resource use and management; to take the interests of individuals, companies, and society into consideration at equal level as much as possible (Alp \& Kılıç, 2014).

Corporate governance is the design of a corporation management framework by taking the interests of shareholders and other stakeholders into consideration so as to have a sustainable value. In a broader definition, corporate governance is defined as a type of good governance, along with the objectives of providing sustainable value creation and long-term company sustainability; with the optimum design for the relationships among the board of directors, executives, and other stakeholders and their roles and responsibilities by taking the principles of transparency, equity, accountability, and responsibility into consideration while undertaking corporation activities; with the separation of governance and audit functions; and with showing respect to the rights and interests of other stakeholders while protecting the interests of shareholders (Alp \& K1lıç, 2014). It is at this point that the separation of governance and audit is highly critical. In some corporations, the owner may carry out corporation governance activities. However, if there is no professional governance, it may create serious problems for individuals and organizations linked to the corporation in any way. In this case, the hypercorrect way is to leave the governance to professional managers and the audit functions to other groups. Individual savers and corporate shareholders do not have a voice in governance. Protection of their rights and ensuring that they are properly informed are the natural responsibilities of corporate governance (Denis \& McConnell, 2003).

According to another definition, corporate governance is a system of law, regulation, and voluntary private sector practices which is used to attract capital and human resources, to perform efficiently, to reach targets, and to fulfill legal obligations and social expectations (Dalğar \& Pekin, 2011). 
Corporate governance is the key item in improving economic efficiency and growth and in gaining investor trust. With the simplest definition, corporate governance represents the patterns and processes used in the directing and control of corporations. It is basically the management and control system of a corporation. From a financial point of view, corporate governance specifies the committees responsible for the determination and auditing of financial policies and how the corporation's progress and operation outcomes will be monitored and reported on behalf of the shareholders (Doğan, 2007).

Although corporate governance practices vary based on the legal regulations of the country in which the corporation is located or based on the specific characteristics of the corporation, there are basic principles which are valid in all corporate governance models. These principles are transparency, equitable treatment, accountability, and responsibility. These principles are briefly defined below.

Transparency. Accurate and timely disclosure of information about financial status, ownership, management, objectives and possible risk factors and other relevant financial issues are the inherent characteristics of corporate governance (Karamustafa, Varıc1, \& Er, 2009). In other words, transparency is the disclosure or publicizing of corporation-related financial and non-financial information, except for confidential business information that has not yet been made public, in a timely, fully understandable, interpretable, cost-effective, and easily accessible fashion (Pamukçu, 2011).

Equitable treatment. The equitable and equal treatment principle of corporate governance describes the equitable treatment by corporate management of shareholders and beneficiaries in all operations and activities and the prevention of possible conflicts of interest. Implementation of the equity or equality principle assures the objectivity and reliability of management in corporate operations (Y1lmaz \& Kaya, 2014).

Accountability. Accountability expresses the right to hold accountable and bring to book any individuals or bodies using authority, making decisions, operating or acting in an issue for the authority used, decision made, operation performed, and activity implemented. Accountable individuals are responsible to individuals or bodies by whom they are inspected and audited for proving the compliance of the authority they used, decisions they made, operations they performed, and activities they implemented with the current regulations, specified objective and procedures, ethical rules and the nature of the process with regard to both style and content. In the implementation of the accountability principle, duties, authorities and responsibilities at every level should be clearly defined, authority should be rational, and internal-external audit mechanisms should operate effectively (Alp \& K1lıç, 2014).

Responsibility. This principle describes the implementation of corporate operations in accordance with legal regulations and social values. It is also described as social responsibility. Corporate social responsibility is the governance of corporate financial operations without endangering the interests of any relevant parties (partners, employees, customers, and ultimately entire society) (Aksoylu, 2013).

To summarize, corporate governance is a system including laws, regulations, and voluntary practices used to:

(1) Attract capital and human resources;

(2) Perform efficiently;

(3) Reach targets;

(4) Meet legal obligations and social expectations (Yıldırım \& Bilen, 2014).

In companies which fully practice corporate governance, company prestige is raised and such a case then positively affects financial performance and corporate value (Iwu-Egwuonwu, 2011). 


\section{Perceived Financial Performance}

In the literature, various performance measurement methods have been reported for corporations. Mostly, objective, subjective (perceptual), qualitative, and quantitative methods are used, but sometimes two methods are used together. To measure the qualitative and quantitative financial performance of a corporation, managers are asked to assess the success of the company compared to other businesses in the sector with regard to various financial performance criteria (increase in sales, market shares and assets, turnover, equity and return on assets, decrease in debts, liquidity position, etc.). Such a performance is known as the perceived financial performance (Alpkan, Ergün, Bulut, \& Yllmaz, 2005). Although perceived performance has some kind of validity and reliability problems, because of the difficulties in reaching objective data to assess the financial performance of the companies, unpublished financial statements in non-public companies, not reflecting the real situation and similar factors obligate the use of perceptual information received from the participants.

\section{Literature}

It was observed in the literature that several studies have been performed about the general relationships between corporate governance and perceived performance, but no studies have been performed about the relationships of corporate governance with perceived financial performance. However, there are some studies about the effects of corporate governance on the financial performance of companies.

Leng (2004), in a study titled The Impact of Corporate Governance Practices on Firms' Financial Performance: Evidence From Malaysian Companies, used the data of 77 companies operating in Malaysia during the years of 1996-1999 to investigate the effects of corporate governance practices on the financial performance of companies and reported positive impacts of corporate governance.

Abdelkarim and Alawneh (2009), in a study titled The Relationship Between Corporate Governance and the Performance of Palestinian Firms: An Empirical Study, used the data of 16 companies operating in Palestine during the years of 2003-2006 and reported negative relationships between corporate governance and the financial performance of the firms.

Hassan and Ahmed (2012), in a study titled Corporate Governance, Earnings Management and Financial Performance: A Case of Nigerian Manufacturing Firms, used the data of manufacturing firms operating in Nigeria during the years of 2008-2010 and indicated positive effects of corporate governance on financial performance.

Coşkun and Sayılır (2012), in their study titled Relationship Between Corporate Governance and Financial Performance of Turkish Companies, assessed the data of 31 companies during the years of 2006-2010 and indicated positive impacts of corporate governance on firm value and financial performance but reported a weak relationship between them.

Amba (2014), in a study titled Corporate Governance and Firms' Financial Performance, assessed the financial data of 39 firms operating in Bahrain and reported significant positive effects of corporate governance on financial performance.

Alalade, Onadeko, and Okezie (2014), in a study titled Corporate Governance Practices and Firms' Financial Performance of Selected Manufacturing Companies in Lagos State, Nigeria, used the data of the top 10 manufacturing companies in Nigeria during the years of 2003-2010 and identified significant positive impacts of corporate governance practices on the financial performance of manufacturing firms. 
Kara, Acar Erdur, and Karabiyık (2015), in a study titled Effects of Corporate Governance Level on the Financial Performance of Companies: A Research on BIST Corporate Governance Index (XKURY), investigated the relationships between the corporate governance level and financial performance of companies in the XKURY index during the years of 2006-2012 and did not find a significant relationship between corporate governance level and financial performance.

\section{Research Methodology}

\section{Research Objective, Model, and Hypotheses}

The research universe comprised 100 large-scale manufacturing firms (with a number of employees of 250 and over) operating in the Kayseri Organized Industrial Region. Research data were gathered through questionnaires answered by senior executives of the firms. The questionnaire return rate was $100 \%$.

The questionnaire form created to gather data was composed of three sections. The first section includes questions about the demographic characteristics of the firm executives and the firms and includes questions about the age, gender, educational level and position of executives, establishment date (firm age), sector of operation, and number of employees of the firm. In the second section, there are eight statements about the corporate governance practices of the firms. The third section includes nine statements about the perceived financial performance levels of the firms. Two scales were used in this study. To measure the level of institutionalization, a subjective scale measuring institutionalization and corporate governance levels was used by using the studies of Apaydın (2008), Bhagat and Bolton (2008), and Çakıcı and Özer (2007). To measure the perceived financial performance, a subjective scale used by Alpkan et al. (2005) and which was able to measure qualitative and quantitative performance together was used.

Initially, a reliability test (Cronbach alpha test) was applied to identify the internal consistency and the correlations among the items of the scales. A value of $70 \%$ and over indicates the reliability of the scale (Akgül $\&$ Çevik, 2005). The Cronbach alpha value of the questionnaire was calculated as $86.3 \%$. Thus, it was decided that the questionnaire was reliable and statistical tests could be performed.

A total of 17 questions prepared in a 5-point Likert scale were asked to participants to determine the perceived financial performance and perceived institutionalization level of the firms they are responsible for. The Likert scale was arranged as follows: " 5 = Strongly agree", " 4 = Agree", " $3=$ Undecided", " $2=$ Disagree", and " 1 = Strongly disagree". Scale ranges were calculated by using the formula of "range width/number of groups to be made" and then arithmetic mean ranges considered to assess the research data were arranged as "1.00-1.80 = Strongly disagree", "1.81-2.60 = Disagree", "2.61-3.40 = Undecided", "3.41-4.20 = Agree", and "4.21-5.00 = Strongly agree" (Dede \& Yaman, 2008).

To assess the relationships among the data, a parametric one-way ANOVA test was used if the data satisfied the conditions and a non-parametric Kruskal-Wallis $\mathrm{H}$ test was applied if the data were not available for a parametric test because the independent variables were at a classifying scale and had more than three categories (Bayram, 2013).

Then, Shapiro-Wilk (S-W) and Kolmogorov-Smirnov (K-S) normality tests were applied to determine the parametric or non-parametric test groups to be applied to research data.

The hypotheses for both tests were set as follows:

$\mathrm{H}_{0}$ : Data are normally distributed.

$\mathrm{H}_{1}$ : Data are not normally distributed. 


\section{Results}

The test results are presented in Table 1.

Table 1

Normality Test Results

\begin{tabular}{|c|c|c|c|c|c|c|}
\hline \multirow{2}{*}{ Variable } & \multicolumn{3}{|c|}{ S-W } & \multicolumn{3}{|c|}{$\mathrm{K}-\mathrm{S}$} \\
\hline & $n$ & $\mathrm{~W}$ & $p$ & $n$ & $\mathrm{~K}-\mathrm{S}$ & $p$ \\
\hline Perceived financial performance scores & 100 & 0.841 & 0.000 & 100 & 0.307 & 0.000 \\
\hline Corporate governance & 100 & 0.828 & 0.000 & 100 & 0.303 & 0.000 \\
\hline Sectoral distribution of the firms & 100 & 0.777 & 0.000 & 100 & 0.304 & 0.000 \\
\hline Firm groups based on number of employees & 100 & 0.698 & 0.000 & 100 & 0.368 & 0.000 \\
\hline Firm groups based on ages & 100 & 0.812 & 0.000 & 100 & 0.252 & 0.000 \\
\hline Firm groups based on export/revenue ratio & 100 & 0.684 & 0.000 & 100 & 0.342 & 0.000 \\
\hline
\end{tabular}

K-S and S-W tests were applied to decide which statistical technique should be applied to test the hypotheses. The results of $\mathrm{K}-\mathrm{S}(z)$ and $\mathrm{S}-\mathrm{W}(z)$ analyses revealed that the responses provided for the "perceived financial performance" and "corporate governance" hypotheses did not exhibit a normal distribution.

Since all values for $\mathrm{S}-\mathrm{W}(z)<p$ and $\mathrm{K}-\mathrm{S}(z)<p$, the non-parametric Kruskal-Wallis $\mathrm{H}$ test was chosen to respond to the research question.

The dependent and independent variables to be used in the Kruskal-Wallis H test are provided in Table 2.

Table 2

Kruskal-Wallis H Test Variables

\begin{tabular}{|l|l|}
\hline Dependent variable & Independent variable \\
\hline Perceived financial performance scores & Corporate governance scores \\
\hline Corporate governance scores & Sectoral distribution of the firms \\
\hline & Firm groups based on number of employees \\
\hline & Firm groups based on ages \\
\hline & Firm groups based on export/revenue ratio \\
\hline & Corporate governance \\
\hline
\end{tabular}

The hypotheses created for these tests are as follows:

$\mathrm{H}_{0}$ : The dependent variable is not significantly different from the independent variables.

$\mathrm{H}_{1}$ : The dependent variable is significantly different from the independent variables.

The results are provided in Table 3 .

Table 3

Kruskal-Wallis H Test Results

\begin{tabular}{|c|c|c|c|c|}
\hline \multirow{3}{*}{ Independent variable } & \multicolumn{4}{|c|}{ Dependent variable } \\
\hline & \multicolumn{2}{|c|}{ Perceived financial performance } & \multicolumn{2}{|c|}{ Corporate governance } \\
\hline & $\chi^{2}$ & $p$ & $\overline{\chi^{2}}$ & $p$ \\
\hline Sectoral distribution of the firms & 6.238 & 0.716 & 6.887 & 0.649 \\
\hline Firm groups based on number of employees & 16.761 & $0.000^{* *}$ & 8.557 & $0.014^{* *}$ \\
\hline Firm groups based on ages & 2.633 & 0.621 & 1.974 & 0.741 \\
\hline Firm groups based on export/revenue ratio & 4.402 & 0.354 & 3.378 & 0.497 \\
\hline Corporate governance & 14 & $0.003^{* *}$ & - & - \\
\hline
\end{tabular}

Note. ${ }^{*}: \alpha=0.01 ;{ }^{* *}: \alpha=0.05$. 
The results revealed that the number of employees significantly affected the corporate governance and perceived financial performance scores of the firms $(p<0.05)$. However, the other independent variables, in other words, sectoral distribution, firm age, and export/revenue ratio, did not have any effects on the corporate governance and perceived financial performance scores of the firms.

A correlation test was applied to identify the degree and direction of the relationship among interactive parameters (financial performance score, corporate management score, and number of employees). Since the variables did not exhibit a normal distribution, the Spearman correlation test was applied and the results are provided in Table 4 . The greatest correlation was observed between the number of employees and the perceived financial performance $(r: 0.427 ; \alpha: 0.01)$.

Table 4

Results of Spearman Correlation Analysis

\begin{tabular}{|c|c|c|c|c|}
\hline Spearman correlation & & $\begin{array}{l}\text { Perceived financial } \\
\text { performance }\end{array}$ & Corporate governance & Number of employees \\
\hline \multirow{2}{*}{\multicolumn{2}{|c|}{ Perceived financial performance }} & 1 & & \\
\hline & & - & & \\
\hline \multirow{2}{*}{ Corporate governance } & $r$ & 0.324 & 1 & \\
\hline & $p$ & $0.01^{*}$ & - & \\
\hline \multirow{2}{*}{ Number of employees } & $r$ & 0.427 & 0.234 & 1 \\
\hline & $p$ & $0.000^{*}$ & $0.019^{* *}$ & - \\
\hline
\end{tabular}

Note. ${ }^{*}: \alpha=0.01 ;{ }^{* *}: \alpha=0.05$.

\section{Conclusion}

Today, corporate governance is the key component to improve economic efficiency and growth and to gain investor trust. As corporations are growing and entering world markets, the owners and family businesses of previous periods have had to gradually expand their businesses and account to society. This has forced firms to be transparent, accountable, equitable, and honest to the society they live in.

The measurement made through asking questions to determine how successful executives perceived their firms in terms of financial performance criteria, such as increase in sales and market share, turnover, equity, return on assets, decrease in debts, liquidity position etc., is designated as perceived financial performance.

Although several studies are available about the general relationships between corporate governance and the performance of firms, there are no studies about the relationships of corporate governance with perceived financial performance. Such a case increases the significance of the present study.

In this study, carried out to elucidate the relationships between corporate governance practices and perceived performance, a questionnaire was prepared; the sectors in which the firms are operating, the number of employees, operational age, and export figures of the firms were taken as independent variables and their impacts on perceived financial performance were investigated.

The results revealed that the number of employees had significant effects on the corporate governance and perceived financial performance scores of the firms. Similarly, when corporate governance was taken as the independent variable, it was observed that it had significant effects on perceived financial performance. However, the other independent variables, such as sectoral distribution, firm age, and export/revenue ratio, did not have significant effects on either the corporate governance or the perceived financial performance scores of the firms. 
Finally, a correlation test was applied to identify the degree and direction of relationships among the interactive parameters (financial performance score, corporate management score, and number of employees) and the greatest correlation was observed between the number of employees and perceived performance of the firms.

\section{References}

Abdelkarim, N., \& Alawneh, S. (2009). The relationship between corporate governance and the performance of Palestinian firms: An empirical study. The International Journal of Business and Finance Research, 3(2), 105-120.

Akgül, A., \& Çevik, O. (2005). İstatistiksel Analiz Teknikleri: SPSS'te İşletme Yönetimi Uygulamaları. Emek Ofset, Ankara.

Aksoylu, S. (2013). Relationships of corporate social responsibility (CSR) with accounting information systems: A study. Journal of Modern Accounting and Auditing, 9(12), 1678-1686.

Alalade, Y. S. A., Onadeko, B. B., \& Okezie, O. F. C. (2014). Corporate governance practices and firms' financial performance of selected manufacturing companies in Lagos State, Nigeria. International Journal of Economics, Finance and Management Sciences, 2(5), 285-296.

Alp, A., \& Kılıç, S. (2014). Kurumsal Yönetim, Nasıl Yönetilmeli. Doğan Egmont Yayıncılık ve Yapımcılık Tic. A.Ş., Birinci Bask1, İstanbul.

Alpkan, L., Ergün, E., Bulut, C., \& Yılmaz, C. (2005). Şirket Girişimciliğinin Şirket Performansına Etkileri. Doğuş Üniversitesi Dergisi, 6(2), 175-189.

Amba, S. M. (2014). Corporate governance and firms' financial performance. Journal of Academic and Business Ethics, 8, 1-11.

Apaydın, F. (2008). Kurumsallaşmanın Küçük ve Orta Ölçekli İşletmelerin Performansına Etkileri. ZKÜ Sosyal Bilimler Dergisi, 4(7), 121-145.

Arı, M. (2008). Kurumsal Yönetim ve Finansal Raporlamanın Güvenirliliği. Eskişehir Osmangazi Üniversitesi İ.̇.B.F. Dergisi, $3(2), 43-68$.

Bayram, N. (2013). Sosyal Bilimlerde SPSS ile Veri Analizi. Ezgi Kitabevi, Bursa.

Bhagat, S., \& Bolton, B. (2008). Corporate governance and firm performance. Journal of Corporate Finance, 14(3), 257-273.

Çakıcı, A., \& Özer, B. S. (2007). Mersin'de Faaliyet Gösteren Küçük ve Orta Ölçekli İşletmelerin Kurumsallaşma Göstergeleri Açısından İncelenmesi. Balıkesir Üniversitesi Sosyal Bilimler Enstitüsü Dergisi, 10(18), 87-110.

Coşkun, M., \& Sayılır, Ö. (2012). Relationship between corporate governance and financial performance of Turkish companies. International Journal of Business and Social Science, 3(14), 59-64.

Dalğar, H., \& Pekin, S. (2011). Kurumsal Yönetim ile Finansal Tablo Manüpülasyonu Arasındaki İlişki: İMKB Kurumsal Yönetim Endeksi'nde Yer Alan Şirketlerde Bir Araştırma. Mali Çözüm Dergisi, Eylül-Ekim Sayısı, pp. 19-43.

Dede, Y., \& Yaman, S. (2008). Fen Öğrenmeye Yönelik Motivasyon Ölçeği: Geçerlik ve Güvenirlik Çalışması. Necatibey Eğitim Fakültesi Elektronik Fen ve Matematik Eğitimi Dergisi, 2(1), 19-37.

Denis, D. K., \& McConnell, J. J. (2003). International corporate governance. Journal of Financial and Quantitative Analysis, $38(1), 1-36$.

Doğan, M. (2007). Kurumsal Yönetim. Siyasal Yayınevi, Birinci Bask1, Ankara.

Hassan, S. U., \& Ahmed, A. (2012). Corporate governance, earnings management and financial performance: A case of Nigerian manufacturing firms. American International Journal of Contemporary Research, 2(7), 214-226.

Iwu-Egwuonwu, R. C. (2011). Corporate reputation \& firm performance: Empirical literature evidence. International Journal of Business and Management, 6(4), 197-206.

Kara, E., Acar Erdur, D., \& Karabiyık, L. (2015). Effects of corporate governance level on the financial performance of companies: A research on BIST corporate governance index (XKURY). Ege Academic Review, 15(2), 265-274.

Karamustafa, O., Varıcı, İ., \& Er, B. (2009). Kurumsal Yönetim ve Firma Performansı: İMKB Kurumsal Yönetim Endeksi Kapsamındaki Firmalar Üzerinde Bir Uygulama. Kocaeli Üniversitesi Sosyal Bilimler Enstitüsü Dergisi, 17(1), 100-119.

Leng, A. C. A. (2004). The impact of corporate governance practices on firms' financial performance: Evidence from Malaysian companies. ASEAN Economic Bulletin, 21(3), 308-318.

Pamukçu, F. (2011). Finansal Raporlama ile Kamuyu Aydınlatma ve Şeffaflıkta Kurumsal Yönetimin Önemi. Muhasebe ve Finansman Dergisi, 50, 133-148.

Yıldırım, S., \& Bilen, A. (2014). Türkiye'de İşletmelerin Kurumsal Yönetim İlkelerine Uyum Notlarının İncelenmesi. Dicle Üniversitesi I.I.'B.F. Dergisi, 4(7), 38-48.

Yılmaz, R., \& Kaya, M. (2014). Kurumsal Yönetim İlkelerinin Muhasebe Etik Kuralları İle İlişkisi. İşletme Bilimi Dergisi, 2(1), $17-35$. 